\title{
Hijrahnya Pelaku Prostitusi: Studi Perubahan Perilaku Mantan Mucikari di Eks- Lokalisasi Bangunsari, Surabaya
}

\author{
Muhammad Zaki \\ Universitas Islam Negeri Sunan Ampel Surabaya \\ Email:muhzaki149@gmail.com \\ Sovie Dina Kumala \\ Universitas Islam Negeri Sunan Ampel Surabaya \\ Email:soviedina08@gmail.com \\ Fadhilah Ramadhani \\ Universitas Airlangga Surabaya \\ Email: fadhilahramadhani1992@gmail.com \\ Suhendi \\ Universitas Islam Negeri Sunan Ampel Surabaya \\ Email: hendydolala14@gmail.com
}

Naskah diterima: 30 Januari 2020 | Naskah disetujui: 17 Februari 2020

\begin{abstract}
Da'wah could be an effective strategy in tackling the problem of prostitution. Da'wah of Kyai Khoiron in Bangunsari localization could become one of the example. In this case, Kyai Khoiron's da'wah has given positive effects that result in fairly drastic change in the behaviour of a former pimp named SN (initial name), who has became very active in religious activities and also a coordinator in a preaching routine forum in her living environment. This study attempts to explore the change of behaviour that was experienced by SN using CEOS theory. As a result, SN experienced behavioral changes through 4 stages: the first stage is problem diagnosing, where SN realizes that becoming prostitute makes her feel so far away to God; the second stage is setting goal of her behavioral change, that is serving her life and death only for God (Allah); third, taking actions by starting to be active in various religious activities in the environment, giving charity and performing prayer and worship rituals regularly; fourth, maintaining change in behavior where she considers the change in her behavior as the way of life that she wants and conceive God as something very valuable in her life.
\end{abstract}

Keywords: CEOS Theory, Behaviour Change, Hijrah, Prostitution, Pimp, Da'wah 


\begin{abstract}
Abstrak
Dakwah dapat menjadi strategi yang cukup efektif dalam menanggulangi masalah prostitusi. Contohnya seperti yang dilakukan oleh Kyai Khoiron di eks-lokalisasi Bangunsari, Surabaya. Salah satu hasil dari dakwah Kyai Khoiron adalah perubahan perilaku yang cukup drastis pada salah seorang mantan mucikari bernama SN (inisial), yang kini telah menjadi sangat aktif dalam kegiatan keagamaan bahkan menjadi penggerak dalam kegiatan pengajian di lingkungannya. Penelitian ini berusaha mendalami bagaimana perubahan perilaku yang terjadi pada SN yang telah banyak menerima dakwah dari Kyai Khoiron, dengan menggunakan teori CEOS. Hasilnya, SN mengalami perubahan perilaku melewati 4 tahapan: pertama diagnosa masalah, dimana SN menyadari bahwa profesinya sebagai mucikari dapat membuatnya jauh dari Allah; kedua menetapkan tujuan perubahan perilaku, dimana SN memiliki tujuan agar dirinya dapat mengabdi hidup mati hanya untuk Allah; ketiga mengambil langkah perubahan dengan berhenti dari profesi mucikari, mulai aktif dalam berbagai kegiatan keagamaan di lingkungan, bersedekah, dan melakukan ibadah-ibadah ritual; keempat mempertahankan perubahan perilakunya secara stabil karena ia menganggap perubahan perilakunya sebagai cara hidup yang ia inginkan dan menganggap Allah sebagai sesuatu yang sangat bernilai dalam hidupnya.
\end{abstract}

Kata Kunci: Teori CEOS, Perubahan Perilaku, Hijrah, Prostitusi, Mucikari, Dakwah

\title{
Pendahuluan
}

Fenomena bisnis prostitusi, spesifiknya prostitusi heteroseksual dengan wanita sebagai pekerja seks-nya, secara tradisional dianggap sebagai suatu fenomena yang "natural" dan "universal". Profesi pekerja seks komersial (PSK) sendiri dianggap sebagai profesi wanita yang paling tua di dunia (Järvinen, 1993: 608). Padahal banyak sekali risiko dari fenomena prostitusi ini, diantaranya seperti infeksi menular seksual (Verscheijden et al., 2015: 2) dan keterlambatan capaian perkembangan moral (Maskota, 2016: 2). Wali Kota Surabaya, Tri Rismaharini, pernah mengisahkan bahwa ada seorang PSK yang telah berusia 60 tahun yang sering mendapatkan pelanggan dari kalangan pelajar SD maupun SMP (Faizal, 2014). Kejadian tersebut menunjukkan bahwa fenomena prostitusi ini memiliki pengaruh yang cukup mengkhawatirkan dalam merusak moral anak-anak.

Islam sendiri juga melarang zina, yang merupakan aktivitas utama dalam bisnis prostitusi. Bukti larangan tersebut dapat dilihat dari firman Allah swt dalam surat AlIsro' ayat 32, yang memberikan larangan bahkan untuk sekedar mendekati zina, dan surat An-Nur ayat 2, yang memerintahkan agar memberikan sanksi kepada siapapun yang berzina berupa hukuman cambuk seratus kali. 


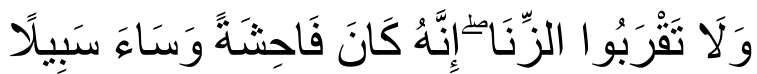

Dan janganlah kamu mendekati zina; sesungguhnya zina itu adalah suatu perbuatan yang keji. Dan suatu jalan yang buruk. (QS Al-Isro' : 32)

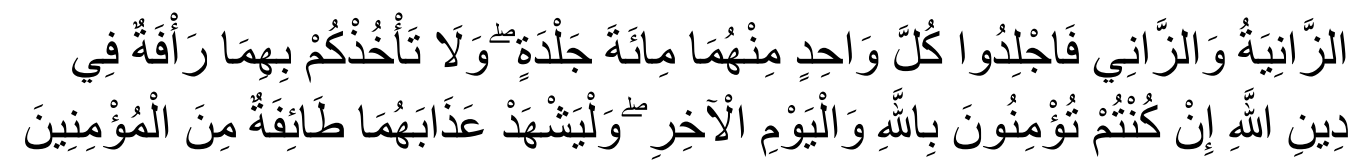

Perempuan yang berzina dan laki-laki yang berzina, maka deralah tiap-tiap seorang dari keduanya seratus dali dera, dan janganlah belas kasihan kepada keduanya mencegah kamu untuk (menjalankan) agama Allah, jika kamu beriman kepada Allah, dan hari akhirat, dan hendaklah (pelaksanaan) hukuman mereka disaksikan oleh sekumpulan orang-orang yang beriman. (QS An-Nur : 2)

Indonesia sebagai negara yang mayoritas penduduknya memeluk agama Islam dan merupakan negara dengan populasi penduduk muslim terbesar di dunia (Diamant, 2019) telah melakukan serangkaian upaya untuk mengatasi fenomena prostitusi ini, baik yang dilakukan oleh pemerintah ataupun lembaga lainnya. Diantaranya yang paling gencar dilakukan adalah dengan melakukan penutupan lokalisasi (Kardi, 2018). Namun pendekatan tersebut nampaknya tidak sepenuhnya efektif untuk memberantas prostitusi. Di era digital, dengan muculnya cyber society, aktivitas prostitusi masih tetap berlanjut dan bergeser ke arah transaksi virtual. Praktek-praktek prostitusi yang ditawarkan lewat media online semakin berkembang pesat dengan semakin maraknya penggunaan internet (Laksono \& Magfiraini, 2014: 67). Ini menjadi indikasi bahwa fenomena prostitusi tidak dapat sepenuhnya diberantas melalui penutupan lokalisasi meskipun dapat mengurangi jumlah penyedia jasa prostitusi dan mempersempit ruang gerak mereka (Handayani, 2016). Perlu ada upaya lain yang juga dilakukan untuk bisa memberantas prostitusi.

Dakwah adalah salah satu pendekatan yang bisa menjadi alternatif dalam membantu menyelesaikan masalah prostitusi. Dakwah memiliki tujuan untuk merubah perilaku sasaran dakwah, agar mau menerima ajaran Islam dan mengamalkannya dalam kehidupan sehari-hari, baik yang bersangkutan dengan masalah personal, keluarga, 
maupun sosial kemasyarakatan, sehingga mendapatkan kehidupan yang bahagia baik di dunia dan di akherat (Hafidhuddin, 1998: 78). Apabila dikaitkan dengan fenomena prostitusi, maka dakwah pada pelaku prostitusi memiliki tujuan untuk merubah perilaku, baik penyedia jasa maupun pelanggan prostitusi, agar meninggalkan aktivitas prostitusi -yang dilarang dalam Islam- dan berusaha untuk mengamalkan ajaran Islam dalam kehidupannya.

Dalam bisnis prostitusi, mucikari adalah pihak yang memiliki peran cukup besar. Ia adalah penanggung jawab dan pengelola seluruh aktivitas prostitusi. Mucikari adalah orang yang mencari PSK dan kemudian menawarkannya kepada pelanggan, baik secara langsung maupun melalui perantara (Oktaviari \& Handoyo, 2017). Melihat peranannya, mucikari dapat dikatakan sebagai orang yang menjalankan bisnis prostitusi sebagai mata pencahariannya. Oleh karena itu mucikari cenderung akan sangat berusaha untuk membesarkan bisnis prostitusinya agar pendapatannya dapat semakin meningkat.

Melihat peran mucikari yang sangat signifikan, maka dalam upaya untuk memberantas prostitusi, salah satu yang cukup penting untuk dilakukan adalah dengan menangani mucikari. Apabila dakwah kepada mucikari dapat berhasil sehingga banyak mucikari yang secara sukarela bersedia meninggalkan pekerjaan mucikari-nya dan justru banyak terlibat dalam kegiatan keagamaan, maka perubahan tersebut akan memiliki dampak cukup besar dalam mengatasi bisnis prostitusi. Sehingga dakwah terhadap mucikari dapat menjadi salah satu strategi penting dalam memberantas prostitusi.

Ada beberapa bukti keberhasilan dakwah terhadap pelaku prostitusi, termasuk mucikari, yang dapat membantu menyelesaikan masalah prostitusi di suatu wilayah. Salah satunya adalah yang dilakukan oleh Kyai Khoiron di eks-lokalisasi Bangunsari, Surabaya. Indikator keberhasilannya dapat dilihat dari bagaimana ia mampu membuat PSK di eks-lokalisasi Bangunsari yang awalnya berjumlah sekitar 3000 orang dan tersebar di 15 RT berkurang menjadi sekitar 300 orang dan hanya terkonsentrasi di dua RT (Sunarto, 2013: 351, 357) hingga akhirnya lokalisasi Bangunsari resmi ditutup oleh Pemerintah Kota Surabaya di akhir tahun 2012. Sebagai catatan, pada saat proses penutupan tersebut protes/perlawanan yang terjadi sangat minim, jauh berbeda dengan perlawanan yang terjadi terhadap penutupan lokalisasi lainnya di Surabaya (detikNews, 2014). 
Salah Salah satu mucikari yang telah mengalami perubahan total di ekslokalisasi Bangunsari adalah SN. Ia merupakan mantan mucikari yang dianggap cukup berhasil karena memiliki dua buah hotel yang dijadikannya sebagai tempat untuk menjalankan bisnis prostitusinya. Dua hotel tersebut berada di Jl. Lasem dan Jl. Bangunsari 4. Semenjak eks-lokalisasi Bangunsari ditutup oleh Pemerintah Kota Surabaya, SN telah meninggalkan profesinya sebagai mucikari. Hotel yang dimilikinya telah dijual dan kini ia menjadi jauh lebih aktif dalam berbagai kegiatan keagamaan. Ia mengikuti kelompok pengajian yang dibina oleh istri dari Kyai Khoiron, Ibu Roudhoh, dan bahkan menjadi penggerak atau semacam koordinator dalam kelompok pengajian bulanan di masjid Nurul Fatah yang merupakan masjid terbesar di wilayah Bangunsari, dimana kelompok pengajian tersebut anggotanya meliputi ibu-ibu warga RW 04 Kelurahan Bangunsari dan sekitarnya. Perubahan perilaku pada SN, dari yang awalnya menjalani profesi sebagai mucikari dan tidak banyak melakukan kegiatan keagamaan hingga kemudian meninggalkan profesi mucikari dan menjadi aktif dalam kegiatan keagamaan, dapat menjadi pelajaran penting tentang bagaimana keberhasilan dakwah dalam merubah perilaku mucikari. Oleh karena itu topik ini akan menjadi tema utama dalam penelitian ini.

Untuk memahami bagaimana perubahan perilaku yang terjadi pada SN peneliti menggunakan teori CEOS sebagai pijakannya. Teori ini sebenarnya merupakan teori perubahan perilaku yang berfokus pada perubahan perilaku yang sulit dipertahankan (hard to maintain behaviour), namun ia juga dapat menjelaskan bagaimana perubahan perilaku secara umum (Borland, 2017: 3). CEOS memiliki konsep bahwa secara kontinu perilaku diproduksi oleh proses interaktif dari dua fungsi yang ada dalam diri manusia. Pertama, proses operasional bottom-up yang secara kontinu mencari keseimbangan homeostasis antara kondisi lingkungan dan kebutuhan internal, dengan memproduksi perilaku tertentu. Proses ini dijalankan oleh salah satu fungsi yang disebut sebagai operational system (OS). Kedua, eksekutif proses yang lebih lamban, bersifat top-down, reflektif, dan berbasis linguistik, yang menyediakan kapasitas untuk melepaskan diri dari kemungkinan-kemungkinan masalah yang sedang didapati dan memformulasikan target-target dalam bentuk konseptual beserta tindakan untuk mencapainya. Fungsi ini disebut sebagai ES yang merupakan kependekan dari executive system (Borland, 2017: 4). 
CEOS adalah teori biopsikososial, yang mana memiliki premis bahwa perilaku ditentukan oleh interaksi antara faktor biologis, psikologis, dan lingkungan sosial. Menurut CEOS, di dalam individu, interaksi dengan lingkungan dikelola oleh sistem pemrosesan multi-level yang kompleks (ES dan OS), yang menghubungkan input dari lingkungan (context) dengan keadaan kebutuhan seseorang (fungsi OS), yang kemudian menyebabkannya mendesain suatu perilaku untuk memenuhi kebutuhan tersebut (fungsi ES). CEOS sendiri merupakan singkatan dari Context, Executive, dan Operating System (Borland, 2014: 2). CEOS menteoritisasikan bahwa dalam perubahan perilaku ada setidaknya empat tahapan utama, yakni mendiagnosa masalah (problem diagnosing) menetapkan goal (goal setting), melakukan upaya perubahan (taking action), dan mempertahankan perubahan (maintaining change) (Borland, 2017: 25).

Teori CEOS didesain untuk menjadi cara baru yang komprehensif dalam memahami bagaimana seseorang merubah perilakunya yang telah menjadi kebiasaan (Borland, 2014: 1). Maka dari itu yang menjadi fokus dalam penelitian ini adalah proses perubahan perilaku pada SN -yang telah banyak mendapatkan paparan dakwah dari Kyai Khoiron- dari yang awalnya berprofesi sebagai mucikari dan dekat dengan kegiatan maksiat hingga kemudian meninggalkan profesinya dan menjadi sangat aktif dalam kegiatan keagamaan, dengan menggunakan pendekatan teori CEOS. Tujuan dari penelitian ini sendiri adalah untuk dapat memahami bagaimana proses perubahan perilaku SN secara komprehensif. Penelitian ini menggunakan metode penelitian kualitatif dengan pendekatan analisis fenomenologis interpretatif, yang berusaha untuk mendalami tentang pengalaman detail seseorang dalam rangka mengetahui bagaimana seseorang dalam memahami dirinya dan dunia sosialnya (Shinebourne, 2011).

\section{Teori CEOS}

Teori CEOS pertama kali diperkenalkan oleh Ron Borland pada tahun 2014 lewat bukunya yang berjudul "Understanding Hard to Maintain Behaviour Change" dan kemudian disusul dengan artikelnya yang berjudul "CEOS Theory: A Comprehensive Approach to Understanding Hard to Maintain Behaviour Change" yang terbit di tahun 2017. CEOS adalah teori tentang perubahan perilaku yang secara spesifik berfokus pada perubahan perilaku yang sulit dipertahankan, seperti berhenti merokok, makan makanan sehat, rajin berolahraga, dan sebagainya (Borland, 2017: 3). Teori CEOS berusaha 
mengembangkan konsep mengenai bagaimana alam sadar dan alam bawah sadar dalam mempengaruhi perilaku.

Borland (2014: 31) mendefinisikan perilaku sebagai segala sesuatu yang mencakup apapun dari mulai perilaku spesifik yang terpisah sampai pada perilaku yang terpola secara rutin. Contohnya, berolahraga dapat mencakup dari mulai peregangan kaki sampai berlari beberapa kilometer atau berlari secara rutin 4 kali dalam seminggu.

CEOS menteoritisasikan bahwa perilaku dihasilkan secara kontinu dari interaksi antara dua fungsi dalam diri manusia, yakni ES dan OS. OS memiliki fungsi untuk mencari keseimbangan homeostasis antara keadaan lingkungan dan kebutuhan internal dalam diri manusia dengan memproduksi kecendrungan perilaku. Sedangkan ES berfungsi menyediakan kapasitas untuk melampaui keadaan lingkungan yang sedang dihadapi (tidak terpengaruh pemicuan perilaku oleh lingkungan), dan untuk memformulasikan tujuan dalam wujud konseptual serta mengoordinasikan tindakan untuk mencapainya (Borland, 2017: 4). Dapat dikatakan bahwa ES merupakan kesadaran kita, fungsi yang kita miliki untuk berpikir secara rasional, sedangkan OS adalah alam bawah sadar yang memberikan dorongan-dorongan afektif kepada kita untuk melakukan tindakan tertentu. Apa yang seseorang anggap sebagai "dirinya" atau "aku” adalah ES-nya.

OS bekerja dengan memproduksi jaringan asosiatif yang menstimulasi ES dan/atau memproduksi kecendrungan tindakan. Stimulasi tersebut dapat disebut sebagai dorongan afektif. OS akan selalu dibutuhkan dalam proses menghasilkan perilaku. Sehingga, agar ada tindakan untuk mengejar tujuan dari ES, maka ES perlu untuk menstimulasi dorongan afektif dan kecendrungan tindakan yang lebih besar di dalam OS dibandingkan kecendrungan tindakan yang dihasilkan oleh OS sendiri pada saat

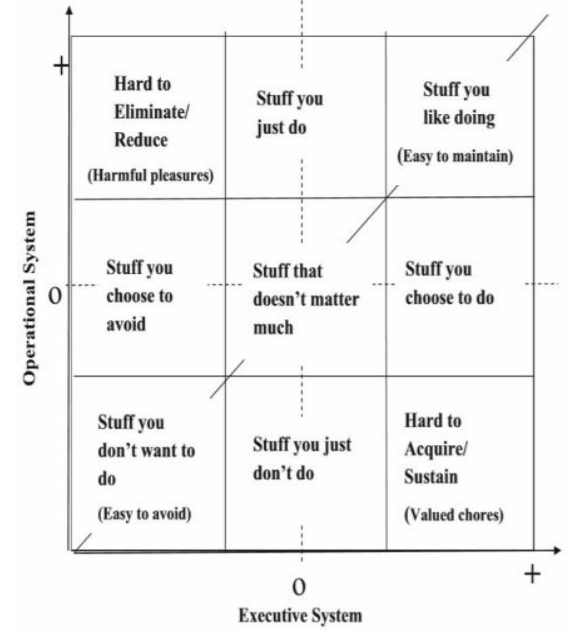

Gambar 1.1 Pemahaman perilaku dilihat dari perbedaan kekuatan dan arah dorongan untuk bertindak pada OS (keinginan untuk melakukan tindakan) dan ES (penilaian rasional terhadap nilai

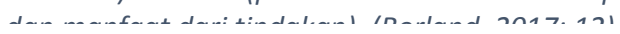

bersamaan (Borland, 2017: 4).

Gambar 1.1 menunjukkan kemungkinan interaksi antara proses ES dan OS. Perilaku yang diinginkan oleh ES tetapi tidak secara konsisten didukung oleh OS, maka sulit untuk dipertahankan atau dimiliki. Sebaliknya, perilaku yang tidak diinginkan oleh ES (perilaku yang sebenarnya ingin kita minimalisir atau hilangkan), 
tetapi sangat didorong oleh OS, maka sulit untuk diminimalisir atau dihilangkan. Itulah kenapa Borland (2014: 11) beranggapan bahwa perilaku yang sulit dipertahankan (HTM behaviour) dapat dibedakan menjadi dua, yakni perilaku yang sulit untuk dimiliki atau dirutinkan (hard to acquire / hard to sustain behaviour) dan perilaku yang sulit diminimalisir atau dihilangkan (hard to reduce / hard to eliminate behaviour).

Gambar 1.1 menunjukkan kenyataan bahwa sebagian besar perilaku sebenarnya tidak bermasalah (Borland, 2017: 11). Seseorang dapat melakukan sebagian besar kegiatannya sehari-hari tanpa banyak terjadi pertentangan dalam dirinya, namun yang menjadi masalah di sini adalah ketika dorongan dari OS bertentangan dengan apa yang menjadi tujuan/keinginan dari ES, maka perilaku tersebut merupakan perilaku yang sulit untuk dipertahankan (hard to maintain/HTM behaviour).

Konsekuensi langsung dari perilaku (rasa senang atau tidak senang/menderita) mempengaruhi kemungkinan terjadinya perilaku berulang melalui mekanisme pengondisian yang dikendalikan oleh OS. Sedangkan konsekuensi tertunda (tidak langsung dialami setelah melakukan tindakan) membutuhkan peran ES untuk membuat link -yang menunjukkan keterkaitan antara tindakan dan konsekuensi tersebut secara konseptual- agar dapat mempengaruhi perilaku yang akan datang. Seringkali perilaku dipandang sebagai diinginkan atau bermasalah karena dikaitkan dengan akibat-akibat di masa depan, bukan akibat yang langsung didapatkan (Borland, 2014: 34). Contohnya seorang mucikari bisa jadi menganggap perilakunya dalam menjalankan profesi sebagai mucikari sebagai perilaku yang keliru/bermasalah. Namun karena konsekuensi langsung dari profesi tersebut yang memberikan banyak kesenangan, dengan mendapatkan banyak uang tanpa banyak jerih payah, membuat akhirnya meninggalkan profesi mucikari menjadi cukup sulit.

Tujuan dari perubahan perilaku adalah untuk menambah nilai intrinsik yang memadai ke dalam perilaku yang diinginkan (oleh ES) untuk memindahkan mereka ke tahap 'choose to do' dan bahkan ke tahap 'want to do', sementara untuk perilaku yang sulit diminimalisir, adalah dengan menambahkan valensi negatif mengubah mereka ke tahap 'choose to avoid' atau tahap 'want to avoid' (Borland, 2014: 35). 


\section{Proses Perubahan Perilaku Menurut Teori CEOS}

Proses perubahan perilaku berdasarkan CEOS (Borland, 2017: 25) memiliki beberapa tahap yang melibatkan ES dan OS seseorang, yaitu:

\section{Diagnosa masalah (Problem Diagnosing)}

Diagnosis masalah mencakup analisis terhadap masalah, termasuk tingkat keseriusannya dan urgensinya. Individu perlu memiliki informasi yang cukup untuk menyimpulkan bahwa dia atau mereka memiliki masalah yang cukup serius sehingga membutuhkan perhatian khusus. Untuk bisa membuat seseorang menyadari masalah tersebut salah satu caranya dapat dengan menggunakan komunikasi yang persuasif, misalnya, penggambaran secara grafis dari kerugian atau serangan, atau sebuah akibat/hasil dari pengalaman pribadi.

\section{Menetapkan Tujuan Perubahan (Setting Goals)}

Ketika sebuah masalah atau kerugian telah nampak dengan jelas, langkah selanjutnya adalah menentukan apa yang harus dilakukan. Seringkali, solusi (keinginan di masa depan) dapat dirumuskan ketika masalah muncul. Pemilihan tujuan atau dalam hal ini solusi dari masalah dapat dilihat dari berbagai sisi, mulai dari yang sederhana hingga bentuk solusi yang dapat berkembang seiring dengan berjalannya waktu. Penentuan solusi ini bisa dipengaruhi oleh arahan mengenai perilaku atau tindakan tertentu dari orang lain (dari sumber manapun, mulai agama sampai ilmu pengetahuan), contohnya seperti ketika seorang pekerja seks komersial menyadari bahwa profesi yang dijalaninya salah, lantas ia mendapatkan arahan dari seorang ustaz bahwa ia harus bertaubat dengan memohon ampun kepada Allah dan rajin beribadah. Penentuan solusi juga dapat dipengaruhi oleh analisis pribadi serta pengalaman langsung dan pengalaman orang lain yang berkesan baginya. Faktor penentu utama dari tujuan yang dipilih adalah seberapa besar tujuan/niat tersebut diinginkan dan dapat dicapai. Aspek penting dalam menetapkan tujuan perubahan adalah seberapa besar keinginan (desirability) dan kemungkinan tercapainya (achievability) tujuan tersebut. Besarnya keinginan akan sangat dipengaruhi oleh outcome expectancy, yakni hasil/dampak yang diharapkan dari tercapainya tujuan tersebut. Apabila seseorang menganggap bahwa suatu tujuan dapat memberikan dampak yang bernilai tinggi baginya, maka semakin ia ingin untuk mengejar tujuan tersebut. 


\section{Mengambil Langkah Perubahan (Taking Action)}

Tindakan sering dipicu oleh peristiwa eksternal seperti diskusi, penjelasan dari media massa, keberhasilan orang lain, dan sebagainya. Pencapaian tujuan dibatasi oleh fungsi OS dalam hal langkah mana yang sesuai bagi seseorang. Untuk mencapai suatu tujuan dibutuhkan skrip (script) atau rencana dengan analisis akurat yang tepat tentang apa saja yang diperlukan.

Kebanyakan perencanaan atau skrip dibuat pasca membuat keputusan untuk mengambil langkah pertama perubahan. Setelah keputusan untuk mengambil langkah pertama perubahan dibuat, langkah selanjutnya adalah menguraikan skrip untuk langkah-langkah berikutnya, atau menggunakan skrip yang sebelumnya telah dikembangkan dan mulai menerapkannya. Setidaknya skrip harus berisi tentang kapan akan memulai langkah perubahan dan strategi umum yang akan digunakan dalam mencapai tujuan perubahan.

\section{Mempertahankan Perubahan (Maintenance)}

Dalam proses mempertahankan perubahan perilaku, tantangan utamanya adalah adanya risiko untuk kambuh (relapse), di mana perilaku atau kebiasaan lama yang ingin dihilangkan muncul kembali setelah berhasil melakukan perubahan perilaku selama beberapa waktu. Kekambuhan tersebut dapat muncul apabila tidak ada penyesuaian yang memadai baik pada proses OS maupun ES. Dalam mempertahankan perubahan ini juga perlu ada skrip. Skrip dalam mempertahankan perilaku membantu menjaga seseorang untuk selalu berada di jalur yang tepat dalam proses perubahan, serta dapat membuatnya lebih memprioritaskan langkah-langkah perubahan dalam kesehariannya, dan menghindari gangguan. Sehingga, agar skrip atau perencanaan tersebut efektif maka diperlukan kepekaan terhadap kebutuhan OS dan faktor-faktor kontekstual, serta strategi untuk bertahan, dan bebearpa bentuk komitmen untuk bertahan saat menghadapi ketidaknyamanan diri pada proses perubahan perilaku.

Skrip yang efektif memungkinkan seseorang untuk sadar dan menerima perubahan sebagai cara hidup baru yang diinginkan dan bertindak sebagai panduan tentang bagaimana mengintegrasikan perubahan tersebut dalam aspek-aspek yang berharga dalam kehidupan mereka. 


\section{Hasil dan Pembahasan}

\section{Proses Perubahan Perilaku SN}

Diagnosa Masalah

Tahap diagnosa masalah adalah tahap dimana seseorang menganalisis kekhawatirannya terhadap masalah yang dapat ditimbulkan oleh perilakunya, utamanya terkait dengan seberapa serius dan mendesak masalah tersebut (Borland, 2017: 25). Diagnosa masalah dapat dikatakan sebagai gerbang awal seseorang untuk berusaha merubah perilakunya. Ini karena, tanpa menganggap bahwa perilakunya bermasalah, seseorang tidak akan memiliki keinginan untuk merubahnya.

Terkait dengan proses diagnosa masalah, pada saat wawancara dengan SN, peneliti menanyakan apakah ia telah memiliki pikiran/niatan untuk menutup bisnis prostitusinya sebelum ditutup oleh Pemkot Surabaya, SN menjawab, “Iya, ya mungkin ada. Ya kita ditutup dengan adanya pemkot itu juga berterima kasih ... Ya kita kan sudah tua untuk apasih yang dicari di dunia, ... jadi kita doa itu ya supaya lebih baik, sudah tua apa yang dipikir." (Wawancara dengan SN pada 9 September 2019).

Jawaban SN tersebut mengindikasikan ketidakyakinannya tentang apakah sebelum eks-lokalisasi Bangunsari ditutup ia sudah terbersit keinginan untuk menutup hotelnya. SN menganggap bahwa penutupan yang dilakukan oleh Pemkot Surabaya itulah yang menjadi pemicu ia kemudian menutup bisnis prostitusinya. Itulah kenapa kemudian ia berterima kasih dengan adanya penutupan lokalisasi tersebut.

SN sebenarnya memiliki opsi untuk menggunakan aset yang ia miliki untuk tetap melanjutkan bisnis prostitusinya. Karena masih memiliki dua hotel yang akhirnya ia jual pasca penutupan eks-lokalisasi Bangunsari. Ditambah lagi keuntungan bisnisnya dulu nampaknya cukup besar. Ini seperti pengakuan dari teman dekat SN yang bernama Ibu Piana kepada peneliti, "Dulu itu waktu saya ke rumahnya (SN) itu uangnya keleleran di kasur-kasur, di meja-meja ... Kerjanya dia lontang-lantung dapat uang, yang kerja kan orang lain ya kasarnya begitu, duduk manis uang datang sendiri." (Wawancara dengan Ibu Piana pada 30 September 2019)

SN juga telah puluhan tahun menjalani bisnis prostitusi, yang artinya ia berpengalaman, sehingga sebenarnya paham betul tentang bagaimana memulai lagi bisnis prostitusi tersebut dengan modal besar yang ia miliki pasca lokasi bisnisnya yang lama sudah ditutup. Ia bahkan juga punya opsi untuk menentang penutupan, seperti 
yang dilakukan pelaku bisnis prostitusi di eks-lokalisasi Dolly pada saat Dolly ditutup. Namun ia tidak melakukan itu semua. Ini menunjukkan bahwa SN menganggap bahwa penutupan tersebut adalah baik baginya, meskipun merugikan secara finansial. Kondisi ini tentu konsisten dengan yang ia ucapkan bahwa dirinya tidak mencari apa-apa lagi di dunia mengingat usianya yang sudah tua dan ucapan terima kasihnya atas penutupan eks-lokalisasi Bangunsari oleh Pemkot Surabaya.

Pada suatu kesempatan wawancara SN sempat membuat pernyataan, "Kita sudah tua, sudah segalanya sudah cukup, saya hanya ingin mengabdi hidup mati kembali ke Allah. Soalnya sudah cukup tau diri dengan diberi rizki berlimpah." (Wawancara dengan SN pada 15 September 2019). Peneliti memiliki analisis bahwa ungkapan sudah tua dari SN ini mengisyaratkan bahwa dirinya telah dekat dengan kematian, yang artinya kesempatan hidupnya di dunia tinggal sedikit. Seseorang yang telah mati tidak akan memiliki kesempatan lagi untuk beribadah kepada Allah atau mengumpulkan bekal untuk kehidupan akherat. Di sisi lain, SN merasa profesinya dulu sebagai mucikari adalah sesutu yang buruk, mengingat profesi tersebut identik dengan perbuatan maksiat. Ini tersirat dari bagaimana SN sempat melontarkan bahwa ia bersyukur bahwa saat ini sudah menjadi orang yang baik, “Jadi pinginnya kita itu dekat dengan Allah. Ndak ada keinginan itu (kembali membuka bisnis prostitusi), malah bersyukur kita menjadi orang yang baik." (Wawancara dengan SN pada 15 September 2019).

Oleh karena itu peneliti menganalisis SN memiliki anggapan bahwa jika dirinya tidak berusaha dari sekarang untuk benar-benar beribadah kepada Allah, maka ia khawatir akan jauh dari Allah dan mendapatkan murka-Nya. Padahal murka dari Allah nampak dianggap sebagai sesuatu yang sangat serius oleh SN. Ini terlihat dari bagaimana ia benar-benar ingin agar hidup hingga matinya hanya digunakan untuk beribadah kepada Allah.

Pengabdian atau kedekatan dengan Allah inilah yang nampak sekali menjadi perhatian utama dari SN. Ia merasa bahwa beribadah dan berdo'a kepada Allah serta berusaha untuk dekat dengan-Nya adalah sesuatu yang sangat penting. Kehidupan dunia bagi SN tidak lagi menjadi prioritas, seperti yang ia ungkapkan bahwa tidak ada lagi yang ia cari di dunia. Oleh karena itu SN menganggap bahwa perilakunya yang menjalani profesi sebagai mucikari merupakan masalah yang besar karena dapat 
menjauhkannya dari Allah dan cukup mendesak untuk diselesaikan karena dirinya merasa sudah cukup tua dan dekat dengan kematian.

\section{Menetapkan Tujuan Perubahan}

Seringkali solusi dari perilaku yang bermasalah (tujuan) akan tersugestikan bersamaan dengan kesadaran seseorang bahwa perilaku tersebut bermasalah (Borland, 2017: 25). Pada SN, ketika ia menyadari bahwa dirinya sudah tua dan pekerjaannya sebagai mucikari akan menjauhkannya dari Allah, SN merasa bahwa dirinya harus meninggalkan pekerjaan tersebut dan bertaubat dengan mengabdikan hidupnya untuk Allah dalam hidup dan matinya, seperti yang telah dijelaskan sebelumnya pada poin diagnosa masalah.

Dalam petikan wawancara SN yang menyebutkan bahwa dirinya hanya ingin mengabdi hidup dan mati hanya untuk Allah serta keinginannya untuk dekat dengan Allah, menunjukkan bahwa ia takut apabila jauh dari Allah dan mendapatkan murkaNya, yang disebabkan oleh perilakunya dahulu saat menjalani profesi mucikari. Maka kemudian solusi yang ia sebutkan adalah dengan mengabdikan hidup dan matinya kepada Allah dan ingin dekat dengan-Nya. Ini menunjukkan bahwa SN menjadikan pengabdian/ibadah kepada Allah sebagai tujuan dari perubahan perilakunya.

Konsep tentang pengabdian/ibadah kepada Allah dan dekat dengan-Nya ini menjadi solusi dikarenakan SN memiliki keyakinan bahwa apabila dirinya dekat dengan Allah maka Allah akan mengabulkan apapun yang diinginkannya. Ini seperti yang diungkapkan SN berikut ini:

Kita tidak bosan-bosan untuk salat tahajjud itu untuk meminta ternyata Allah memberi segalanya. Pokoknya kita itu tidak segansegan dan tidak bosen-bosen meminta kepada Allah pasti akan dikabulkan, sekarang saya masih puasa (suro), sampai 4 hari, kemarin tgl 1 puasa sampai senin kamis, rabu makan kamis puasa sampai sekarang. (Wawancara dengan SN pada 9 September 2019)

Ini menunjukkan bahwa ada hasil/dampak dari tercapainya tujuan tersebut yang benar-benar diharapkan oleh SN. Ia beranggapan bahwa ia akan dapat meminta apapun kepada Allah apabila dirinya dekat dan rajin beribadah kepada Allah. Variabel tentang dampak yang diharapkan (outcome expectancies) dari tujuan ini dalam teori CEOS diasumsikan memiliki pengaruh terhadap tingkat keinginan (desirability) seseorang dalam mencapai tujuan yang ditetapkan (Borland, 2014: 128). Semakin tinggi nilai dari 
dampak tersebut maka semakin tinggi pula keinginan seseorang untuk mencapai tujuannya. Maka apabila SN menganggap dampak yang ia harapkan dari tujuan tersebut adalah membuat segala keinginannya dikabulkan, maka nilai dari dampak tersebut dianggap memiliki nilai yang besar. Karena terkabulkannya keinginan tentu merupakan sesuatu yang akan sangat didambakan oleh tiap orang.

\section{Mengambil Langkah untuk Berubah}

Pengambilan langkah untuk berubah seringkali dipicu oleh kejadian-kejadian eksternal. Untuk mencapai tujuan, butuh skrip dengan analisis yang akurat mengenai apa yang dibutuhkan. Keakuratan tersebut bergantung pada kegunaan dari pengetahuan yang dimiliki dan ide-ide yang ada dalam pikiran seseorang (Borland, 2017: 27).

Awal kali SN mencoba untuk berubah, dengan menutup hotel yang dijadikan sebagai sarana menjalankan bisnis prostitusinya, adalah ketika Pemkot Surabaya menutup lokalisasi Bangunsari. Ini seperti yang diucapkan oleh SN dalam wawancara ketika ditanyakan kapan menutupnya, "Kalau ngga salah tahun 13 (2013), pada waktu Pemkot nutup."1 (Wawancara dengan SN pada 15 September 2019)

Ibu Piana, seorang teman dekat SN dan salah satu pegiat lingkungan di Bangunsari juga mengonfirmasi bahwa SN menutup bisni prostitusinya bersamaan dengan penutupan lokalisasi Bangunsari oleh Pemkot Surabaya. Ketika ditanya oleh peneliti kapan SN benar-benar berhenti dari profesi mucikarinya, Ibu Piana menjawab, "Penutupan ini kan tahun 2012 ya, ya mulai itu." (Wawancara dengan Ibu Piana pada 30 September 2019)

Melihat bahwa SN tidak melanjutkan bisnis prostitusinya meskipun ia masih memiliki kesempatan untuk melakukannya, ini menunjukkan bahwa penutupan tersebut adalah langkah awal SN untuk mencapai tujuannya dalam beribadah kepada Allah di sisa hidupnya.

Pasca penutupan tersebut SN aktif dalam berbagai kegiatan agama. Ia aktif dalam banyak kegiatan pengajian yang ada di lingkungan rumahnya di Bangunsari, seperti mengaji di Pondok Pesantren Kyai Khoiron yang ia lakukan hampir tiap sore, pengajian Al-Hidayah dan pengajian di masjid Nurul Fatah. Ini seperti yang diceritakan SN, “Kegiatan ibu kalau sore masih ngaji di Haji Khoiron ... Iya tanggal 15 (juga

\footnotetext{
${ }^{1}$ Berdasarkan penelusuran peneliti, Pemkot Surabaya resmi menutup lokalisasi Dupak Bangunsari pada tanggal 21 Desember 2012 (detikNews, 2014). Penuturan SN kurang tepat. Dan nampak SN juga ragu terhadap jawabannya tersebut dengan mengucapkan "kalau ngga salah".
} 
ngaji) di Nurul Fatah tanggal 10 di Al-Hidayah." (Wawancara dengan SN pada 9 September 2019)

Selain itu SN juga aktif dalam melaksanakan ibadah-ibadah ritual lainnya seperti sholat dan puasa, baik yang hukumnya wajib maupun sunnah, seperti yang ia sampaikan berikut ini:

Kita puasa tidak satu saja sunnah, seperti sholat tidak wajib saja ada sunnah-nya, jadi menambah ... Kita tidak bosan-bosan untuk salat tahajud itu untuk meminta ternyata Allah memberi segalanya ... sekarang saya masih puasa suro, sampai 4 hari, kemarin tanggal 1 puasa sampai senin kamis, rabu makan kamis puasa sampai sekarang (senin)... sekarang ya masih sholat tahajud ya tasbih kalau habis isya sholat tahajud istimewa hajat istimewa. (Wawancara dengan SN pada 9 September 2019)

Selain itu SN juga aktif menyumbang makanan untuk beberapa acara di lingkungannya, seperti konsumsi untuk pengajian (berupa kue), untuk lansia yang disantuni dalam pondok pesantren Kyai Khoiron, dan sebagainya. Ini seperti yang ia sampaikan oleh SN, "Saya ikut kelompoknya (Kyai Khoiron), saya melayani makanan kue untuk lansia." (Wawancara dengan SN pada 9 September 2019). Dan yang disampaikan oleh Ibu Piana sebagai berikut:

Kemarin itu kan ada pengajian jadi kue-kue itu dari dia (SN) semua sebelum losmennya ditutup itukan uangnya banyak. Setelah itu penutupan dia kan ngasih infaq (untuk kue), sampai saya gini "mi kalau ndak punya uang wes ndak usah mi" "enggak bunda lek gitu-gitu saya punya" kan sudah berkurang (penghasilan) mas ya, beda jauh mas. (Wawancara dengan Ibu Piana pada 30 September 2019)

Semua usaha yang dilakukan SN, dari mulai menutup bisnis prostitusinya (berhenti dari profesi mucikari), rajin mendirikan sholat dan puasa (baik yang wajib maupun sunnah), hingga rajin bershodaqoh dengan menyumbang makanan sangat relevan dengan tujuannya untuk hanya beribadah kepada Allah dalam hidup dan matinya. Skrip atau ide-ide tentang apa saja langkah yang perlu dilakukan tersebut nampak sangat ditunjang oleh keadaan lingkungan yang banyak memiliki kegiatan dan memberikan bimbingan dalam hal ibadah atau keagamaan. Ini terlihat dari banyaknya kegiatan pengajian yang ada di wilayah Bangunsari, terutama yang diadakan oleh Kyai Khoiron lewat Pondok Pesantrennya. Selain itu, menurut Ibu Piana, istri Kyai Khoiron yang bernama ibu Roudhoh juga banyak membimbing mantan mucikari ataupun PSK 
terkait masalah agama. Ia juga sangat membaur dengan warga disana sehingga memiliki kedekatan dengan mereka, dan banyak orang juga yang menurut Ibu Piana juga melakukan konseling dengannya terkait masalah keagamaan ataupun masalah hidupnya secara umum. Ini seperti yang Ibu Piana sampaikan pada saat ditanyakan oleh peneliti apakah SN langsung belajar kepada ibu Roudhoh setelah ia berhenti menjadi mucikari berikut ini:

Ya fokusnya di situ (di Ibu Roudhoh) semua, Majlis Taklim, semua mucikari dan WTS (PSK) di situ, Majlis Taklim (kelompok mengaji yang dibimbing oleh Ibu Roudhoh) sama AlHidayah. Antara Majlis Taklim sama Al-Hidayah sama, kalau Majlis Taklim fokus di TPI (Taman Pendidikan Islam) kalau AlHidayah itu khusus RW 4 satu bulan sekali, kalau Majlis Taklim ngajinya ibu-ibu setiap hari (di pondok) ada khataman juga ada wisuda khataman juga di situ kayak TPQ anak-anak kecil itu. Ada ceramah dari $\mathrm{H}$. Khoiron juga, ada konseling kalau curhat personal ya ada sama $\mathrm{Hj}$. Khoiron (Ibu Roudhoh) itu, kan fokusnya ngaji di situ. Jadi kayaknya basic agama dari situ semua, saya juga kalau missal ada apa-apa ya ke situ minta jalan keluarnya, beliau mau nerima satu-satu orang gitu, Bu Khoiron kalau PKK ya ikut, walaupun istrinya pak ustaz ya ikut kegiatankegiatan kayak ibu-ibu biasa tiap bulan ya ketemu arisan pengajian PKK ya ketemu.

\section{Mempertahankan Perubahan}

Skrip dalam mempertahankan perubahan perilaku dapat membantu seseorang untuk dapat stabil dalam perubahan perilakunya. Borland (2017: 12) memiliki konsep bahwa skrip yang efektif dalam mempertahankan perubahan perilaku adalah skrip yang dapat menyebabkan seseorang untuk menerima perubahan perilakunya sebagai jalan hidup baru yang diinginkan (desirable new way of living) dan dapat menjadi panduan tentang bagaimana mengintegrasikan perubahan perilaku tersebut kedalam aspek-aspek yang dianggap bernilai dalam hidupnya.

Bisa dikatakan bahwa perubahan perilaku SN sangatlah stabil. Artinya setelah meninggalkan pekerjaannya sebagai mucikari ia sama sekali tidak ada lagi keinginan untuk kembali membuka bisnis prostitusi. Ini seperti jawaban SN dalam wawancara sebagai berikut, ketika peneliti menanyakan apakah sempat ada keinginan untuk kembali lagi pada pekerjaannya yang lama:

Endak. Endak. Allah sudah memberi rejeki kita berlimpah ... Malah, kami jadi dekat sekali dengan Allah, jadi ndak ada hati 
yang macam-macam untuk penginapan, endak. Sudah, alhamdulillah. Cukup segala sudah dipenuhi oleh Allah ... Ndak ada hati ingin ini ingin itu... (Wawancara dengan SN pada 15 September 2019)

SN nampak merasa bahwa hidup yang dijalaninya (way of live-nya) sekarang merupakan suatu anugrah dari Allah. Ini karena ia merasa telah diberikan hidayah oleh Allah sehingga saat ini menjadi lebih baik. Ini seperti yang ia ucapkan dalam wawancara berikut ini:

Soalnya sholat itu mungkin ya pengalaman saya, kalau orangnya (rumah) dekat sama musholla tapi hatinya belum deket dengan Allah mungkin belum bisa, mungkin Allah belum membuka hatinya, tapi walaupun kita dulunya jelek Allah memberi jalan (maka akan berubah). Orang baik kayak apa orangnya sugih (kaya) kayak apa tapi kalau ngga diberi jalan oleh Allah (tetep tidak bisa). Allah satu itu saya percaya, memamg segala sesuatu dari Allah, kalau hati dibuka oleh Allah maka semuanya bisa berubah. Dulu saya juga gitu mungkin karena saya masih ada agama, dituntun dengan ini. (Wawancara dengan SN pada 9 September 2019)

Ada beberapa konsep yang nampak benar-benar mempengaruhi SN dalam perubahan perilakunya dan konsep tersebut benar-benar memiliki bekasan emosional yang cukup mendalam, sehingga kemudian sering ia ungkapkan berkali-kali dalam wawancara. Konsep tersebut adalah berkaitan dengan segala pemberian dari Allah yang telah membuatnya berada dalam posisi seperti sekarang. Ini terlihat dari seringnya ia mengulang beberapa hal yang membantunya bisa keluar dari kegiatan prostitusi. Seperti ketika ia berterima kasih karena Pemkot Surabaya menutup lokalisasi Dupak Bangunsari, ia bersyukur karena telah menjadi lebih baik, ia merasa bahwa perubahannya adalah karena Allah, ia merasa diberikan rizki berlimpah oleh Allah Swt meskipun penghasilannya jauh berkurang dibandingkan saat menjadi mucikari dan sebagainya. Bahkan saat menjelaskan bahwa dirinya sudah tua, sudah tidak ada yang dicari di dunia, SN sempat menangis dan berhenti berbicara.

Keyakinan SN tentang peranan Allah dalam mencukupkan rizkinya dan perubahan perilakunya ini menunjukkan bahwa $\mathrm{SN}$ telah sepenuhnya menerima perubahan perilakunya ini sebagai sesuatu yang benar-benar ia inginkan. Apabila perubahan perilakunya tidak diinginkan, maka ia tidak akan bersyukur dengan adanya perubahan tersebut. Selain itu, keyakinan tersebut menunjukkan bahwa SN telah mampu 
mengintegrasikan perubahan perilaku ke dalam aspek yang bernilai dalam hidupnya. Ini juga terlihat dari bagaimana ia memiliki tujuan perubahan berupa mengabdi pada Allah dalam hidup dan matinya. Dengan kata lain tujuan dari perubahan perilakunya telah menjadi aspek yang sangat bernilai dalam hidupnya. Beberapa konsep tersebutlah yang kemudian dapat membuat SN cukup stabil dalam perubahan perilakunya.

\section{Kesimpulan}

Berdasarkan penjelasan di atas dapat disimpulkan bahwa perubahan perilaku SN dari yang awalnya berprofesi menjadi mucikari dan tidak banyak terlibat dalam kegiatan keagamaan menjadi aktif dalam kegiatan keagamaan dan meninggalkan profesi mucikarinya melewati 4 tahapan. Yang pertama adalah diagnosa masalah, dimana dalam tahapan ini SN menganggap bahwa perilaku lamanya saat menjalani profesi sebagai mucikari merupakan sesuatu yang salah, karena dapat membuatnya jauh dari Allah. Di sisi lain dirinya merasa bahwa umurnya sudah tua, seharusnya tidak mencari apa-apa lagi di dunia.

Tahapan yang kedua dalam perubahan perilaku SN adalah menetapkan tujuan. Dalam tahapan ini SN menganggap bahwa dengan dirinya yang dulu telah mejauh dari Allah dengan menjalani profesi sebagai mucikari, maka dengan umurnya yang sudah tua saat ini ia perlu untuk berusaha mendekatkan diri kepada Allah dengan menjalankan mengabdi kepada Allah dalam hidup dan matinya. SN memiliki harapan bahwa dengan ia dekat kepada Allah maka Allah akan mengabulkan segala keinginannya.

Tahapan ketiga adalah mengambil langkah perubahan. SN mulai mengambil langkah perubahan pada saat Pemkot Surabaya menutup eks-lokalisasi Bangunsari dengan benar-benar sepenuhnya meninggalkan profesinya sebagai mucikari. Ada beberapa langkah lain selain meninggalkan profesi tersebut yang ia lakukan dalam upayanya untuk beribadah kepada Allah, seperti menjalankan ibadah-ibadah ritual dengan banyak melakukan sholat dan puasa, baik yang wajib maupun sunnah; aktif bershodaqoh dengan menyediakan makanan dalam berbagai kegiatan keagamaan maupun untuk lansia; dan aktif dalam berbagai kegiatan keagamaan di lingkungannya.

Tahapan keempat yang dilewati oleh SN dalam perubahan perilakunya adalah mempertahankan perubahan. Dapat dikatakan bahwa SN mampu mempertahankan perubahan perilakunya secara stabil. Ia tidak ada keinginan sama sekali untuk kembali 
lagi menjadi mucikari dan benar-benar menganggap bahwa apa yang dijalaninya sekarang dalam hidupnya ini adalah sesuatu yang memang benar-benar ia inginkan.

\section{Referensi}

Borland, R. (2014). Understanding Hard to Maintain Behaviour Change a Dual Process Approach. Wiley Blackwell.

Borland, R. (2017). CEOS Theory: A Comprehensive Approach to Understanding Hard to Maintain Behaviour. Applied Psychology: Health and Well-Being, 9(1), 3-35. https://doi.org/doi:10.1111/aphw.12083

detikNews. (2014, Juni 19). Beda Dupak Bangunsari dan Dolly, 2 Lokalisasi yang Sukses Ditutup Risma. detik.com. https://news.detik.com/berita-jawa-timur/d2613638/beda-dupak-bangunsari-dan-dolly-2-lokalisasi-yang-sukses-ditutup-risma

Diamant, J. (2019). The Countries with the 10 Largest Christian Populations and the 10 Largest Muslim Populations. https://www.pewresearch.org/facttank/2019/04/01/the-countries-with-the-10-largest-christian-populations-and-the10-largest-muslim-populations/

Faizal, A. (2014). Cerita Buram Temuan Risma dari Balik Gemerlap Lokasi Prostitusi... https://ekonomi.kompas.com/read/2014/02/28/0147046/Cerita.Buram.Temuan.Ris ma.dari.Balik.Gemerlap.Lokasi.Prostitusi.

Hafidhuddin, D. (1998). Dakwah Aktual. Gema Insani.

Handayani, M. S. (2016, September 23). Penutupan Lokalisasi: Selamat Datang Prostitusi Online. https://tirto.id/penutupan-lokalisasi-selamat-datang-prostitusionline-bkkF

Järvinen, M. (1993). Prostitution in Helsinki: A Disappearing Social Problem? Journal of the History of Sexuality, 3(4), 608-630. http://www.jstor.org/stable/3704395

Kardi, D. D. (2018). Tutup Ratusan Prostitusi, Target Mensos 2019 Bebas Lokalisasi. https://www.cnnindonesia.com/nasional/20180525150447-20-301270/tutupratusan-prostitusi-target-mensos-2019-bebas-lokalisasi

Laksono, P., \& Magfiraini, R. (2014). Cyber Prostitution: Bergesernya Masalah Sosial ke Dalam Ruang Virtual. Jurnal Analisa Sosiologi, 3(1), 52-69.

Maskota, F. (2016). Perkembangan Moral Individu yang Hidup di Lingkungan Lokalisasi [Skripsi]. Universitas Negeri Semarang.

Oktaviari, N. S., \& Handoyo, P. (2017). Jaringan Sosial Mucikari Pasca Penutupan Lokalisasi Dolly Surabaya. Paradigma, 5(2).

Shinebourne, P. (2011). Interpretative Phenomenological Analysis. In N. Frost (Ed.), Qualitative Researh Methods in Psychology Combining Core Approaches (hal. 44- 
65). Open University Press.

Sunarto. (2013). Kyai dan Prostitusi: Pendekatan Dakwah KH. Muhammad Khoiron Suaeb di Lokalisasi Kota Surabaya. Jurnal Komunikasi Islam, 3(2), 349-366.

Verscheijden, M. M. A., Woestenberg, P. J., Götz, H. M., van Veen, M. G., Koedijk, F. D. H., \& van Benthem, B. H. B. (2015). Sexually Transmitted Infections among Female Sex Workers Tested at STI Clinics in the Netherlands, 2006-2013. Emerging Themes in Epidemiology, 12(1), 12. https://doi.org/10.1186/s12982-0150034-7 